\title{
Density of Aedes Aegypti Larvae Based on Knowledge, Attitude, and Action to Eradicate Mosquito Nest in Daya Market of Makassar City
}

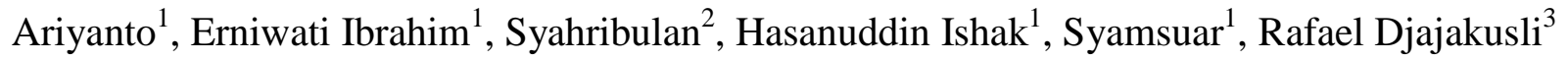

${ }^{1}$ Departement of Environmental Health, Faculty of Public Health, Hasanuddin University, Indonesia

${ }^{2}$ Department of Biology, Faculty of Mathematics and Natural Sciences, Hasanuddin University, Indonesia

${ }^{3}$ Department of Occupational Health and Safety, Faculty of Public Health, Hasanuddin University, Indonesia

Received: October 26, 2020

Revised: November 5, 2020

Accepted: November 8, 2020

\begin{abstract}
Dengue Hemorrhagic Fever (DHF) is a disease caused by a dengue virus infection which is transmitted through the bite of the Aedes aegypti mosquito. To prevent the occurrence of dengue cases, it is necessary to eradicate mosquito nests. The market is one of the public places that has a risk of dengue transmission. This study aims to determine the density description of Aedes aegypti larvae based on the knowledge, attitudes and actions of cleaning managers, traders and visitors to Pasar Daya Makassar City. This type of research is descriptive observational. The research samples were cleaning managers, traders and visitors as well as containers at Pasar Daya and at the respondent's house. Sampling for respondents using purposive sampling method using inclusion and exclusion criteria. The results showed that the number of containers positive for ae.aegypti larvae in the Daya market was 34 containers with a container index value $(\mathrm{CI})=$ $35.4 \%$ and the value of Density Figure (DF) 8 and the presence of Ae.aegypti larvae in the respondent's house (positive) amounting to (51.4\%). At the level of knowledge of respondents in the poor category $(68.6 \%)$, while the attitudes and actions of respondents in the poor category showed a high enough percentage, namely 65.7\%, and (68.6\%). Based on the results of this study, it can be concluded that the density of Aedes aegypti larvae in Pasar Daya Makassar City is in the high category.
\end{abstract}

Keywords: Larval Density, Aedes Aegypti, Knowledge, Attitude, Action

\section{Introduction}

Dengue Hemorrhagic Fever (DHF) is a disease caused by a viral infection that is transmitted through the bites of Ae.aegypti and Ae.albopictus mosquitoes which have previously been infected by the Dengue virus from dengue sufferers. Dengue fever is a disease that is mostly transmitted through mosquito vectors which greatly disturbs the welfare and health status of the community (Boekoesoe, 2015).

The incidence of dengue has spread around the world in the last few decades. The prevalence of infection from DHF is estimated at 3.9 billion people from 128 countries. DHF cases in Indonesia in 2018, totaled 65,602 cases, with a total of 467 deaths (Kementerian Kesehatan, 2019b). The 
incidence of DHF is caused among others due to factors of high mobility, population density, related to environmental conditions and the behavior of the community itself.

South Sulawesi Province DHF cases in 2018 with a total of 2,122 cases. Makassar City is the city with the highest number of DHF cases in all work areas with a total of 256 cases (Dinkes of South Sulawesi Province, 2018). In 2018, there were 4 regions with quite high DHF cases in the city of Makassar, located in the working areas of the Sudiang, Paccerakang, Kassi-Kassi and Sudiang Raya Puskesmas. Of the four regions, it has increased in 2018

In 2016, the Ministry of Health issued a circular with Number PM.01.11 / MENKES / 591/2016 as an action to reduce the prevalence of dengue by regulating the management of $3 \mathrm{M}$ Plus Mosquito Nest Eradication. According to the Ministry of Health (2019a), the one house and one larva observer program (jumantik) is an effective effort in preventing dengue fever.

The eradication of mosquito nests is a $3 \mathrm{M}$ Plus movement which consists of draining the water storage area (TPA), closing the landfill and reusing used items that have the potential for mosquito breeding, plus sprinkling larvicides, using mosquito repellent, keeping larvae eating fish in the landfill, plant mosquito repellent and others. The success of the PSN activity can be measured by the Larva Free Rate (ABJ).

Makassar City is one of the cities in South Sulawesi which cannot be separated from the annual incidence of dengue fever. The role of the government through the 2016 Ministry of Health circular in the prevention of DHF is expected to carry out PSN in each house by empowering the community to become larva monitors, besides that PSN activities need to be carried out in public places

Public places (TTU) are buildings or places used for public service facilities such as hotels, terminals, markets, hospitals, shops, refill drinking water depots, cinemas, tourist attractions, swimming pools, places of worship, restaurants (Kemenkes , 2019a). The market is one of the public places that has the potential to become a breeding habitat for Ae.aegypti (Prasetyowati et al., 2014).

According to Maharani (2015) the market is one of the risk factors for dengue transmission, as indicated by the results of his research showing the container index (CI) level of $42.86 \%$ in the Central Market, $50 \%$ of Simpang Limun market, $60 \%$ of Melati market.

Data from the Makassar City Health Office 2019, Pasar Daya is located in the sub-district that has the highest incidence of dengue fever, namely Biringkanaya District where in 2018 and 2019 there were cases of death due to dengue that were domiciled around Pasar Daya, Makassar City. The purpose of this study is to see the number of larva density and the level of knowledge, attitudes, actions of market managers and traders in Pasar Daya.

\section{Methods}

This research was conducted in Pasar Daya, Makassar City, South Sulawesi Province. This type of research used in this research is descriptive using observational methods, to describe the density of Aedes aegypti larvae in Pasar Daya Makassar City based on the knowledge, attitudes and actions of cleaning managers, traders and market visitors. Sampling of respondents using purposive sampling method using inclusion and exclusion criteria. The data analysis used in this study is univariate analysis to describe the frequency distribution of each variable. 


\section{sResults and Discussion}

The univariate analysis of the results of this study is presented in the form of a distribution table for the independent variable and the dependent variable which is accompanied by a table. With the aim to determine the size of the independent variable and dependent variable. The results of the univariate and bivariate analysis in this study are as follows:

Table 1. Distribution of Ae.aegypti larvae in Respondents' Homes

\begin{tabular}{|c|c|c|}
\hline Presence of Larva & $\boldsymbol{n}$ & \% \\
\hline Negative & 17 & 48.6 \\
\hline Positive & 18 & 51.4 \\
\hline Total & 35 & 100 \\
\hline
\end{tabular}

Primary data sources 2020

Table 1 shows that the presence of larvae in 35 respondents' houses, the presence of larvae in the respondent's house is quite high, namely (51.4\%), compared to the number of houses where aegypti larvae were not found $(48.6 \%)$.

Table 2. Density Distribution of Aegypti Larvae in the Daya Market, Makassar City

\begin{tabular}{|c|c|c|c|c|}
\hline Larvae Density & $\boldsymbol{n}$ & \% & CI Value & DF \\
\hline Negative & 62 & 64,5 & & \multirow{2}{*}{3} \\
Positive & 34 & 35,4 & \multirow{2}{*}{35,41} & \\
\hline Total & 96 & 100 & & \\
\hline
\end{tabular}

Primary data sources 2020

Table 2 shows that out of 96 containers, the presence of negative larvae was 62 containers $(64.5 \%)$, while the presence of positive larvae was 34 containers (35.4\%). The results of the observations showed that the number of Density Figure (DF) 8, namely the density of Ae.aegypti larvae was high.

Table 3. Distribution of container types with the presence of Ae.aegypti larvae in Pasar Daya and in Respondents' Homes

\begin{tabular}{|l|c|c|c|c|}
\hline \multirow{2}{*}{ Type of Container } & \multicolumn{2}{c|}{$\begin{array}{c}\text { Positive Ae.aegypti Larva in } \\
\text { the Daya Market }\end{array}$} & \multicolumn{2}{c|}{$\begin{array}{c}\text { Positive Ae.aegypti larvae in } \\
\text { Respondents }\end{array}$} \\
\cline { 2 - 5 } & $\boldsymbol{n}$ & $\boldsymbol{\%}$ & $\boldsymbol{n}$ & $\%$ \\
\hline Water tub & 5 & 14,7 & 12 & 25.0 \\
\hline Drum & 8 & 23,5 & 18 & 37.5 \\
\hline Bucket & 8 & 23,5 & 16 & 33.3 \\
\hline Water reservoir & 2 & 5,8 & - & - \\
\hline Used tires & 5 & 14,7 & - & - \\
\hline Used cans & 6 & 17,6 & - & - \\
\hline Barrel & - & - & 2 & 4.1 \\
\hline \multicolumn{1}{|c|}{ Total } & 34 & 100 & 48 & 100 \\
\hline
\end{tabular}

Primary data sources 2020 
Table 3 shows that the presence of Ae.aegypti larvae in the Daya Market, Makassar City, is mostly found in drum and bucket containers, amounting to $23.5 \%$, and the presence of Ae.aegypti larvae. The presence of Ae.aegypti larvae in the respondent's house indicated that they were found in many types of drum containers, namely $37.5 \%$.

Table 4. Knowledge Distribution, Attitudes and Actions of Managers, traders and visitors at Daya Market, Makassar City

\begin{tabular}{|c|c|c|c|c|c|c|}
\hline \multirow{2}{*}{ Category } & \multicolumn{2}{|c|}{ Knowledge } & \multicolumn{2}{c|}{ Attitude } & \multicolumn{2}{c|}{ Action } \\
\cline { 2 - 7 } & $\boldsymbol{n}$ & $\mathbf{\%}$ & $\boldsymbol{n}$ & $\boldsymbol{\%}$ & $\boldsymbol{n}$ & \% \\
\hline Good & 11 & 31,4 & 12 & 34,3 & 11 & 31,4 \\
\hline Less & 24 & 68,6 & 23 & 65,7 & 24 & 68,6 \\
\hline Total & 35 & 100 & 35 & 100 & 35 & 100 \\
\hline
\end{tabular}

Primary data sources 2020

Table 4 shows that the level of knowledge of respondents in the unfavorable category is $45.7 \%$, and the attitudes and actions of respondents in the unfavorable category show that the percentage is quite high, namely $65.7 \%$, and (68.6\%).

Table 5. Knowledge of the Attitudes of Managers, Traders and Visitors in Pasar Daya Makassar City

\begin{tabular}{|l|c|c|c|c|c|c|}
\hline \multirow{3}{*}{ Knowledge } & \multicolumn{6}{|c|}{ Attitude } \\
\cline { 2 - 7 } & \multicolumn{2}{|c|}{ Good } & \multicolumn{2}{c|}{ Less } & \multicolumn{2}{c|}{ Total } \\
\cline { 2 - 7 } & $\boldsymbol{n}$ & $\mathbf{\%}$ & $\boldsymbol{n}$ & $\mathbf{\%}$ & $\boldsymbol{n}$ & $\mathbf{\%}$ \\
\hline Good & 12 & 34.3 & 12 & 34.3 & 24 & $\mathbf{6 8 . 6}$ \\
\hline Less & 0 & 0 & 11 & 31.4 & 11 & 31.4 \\
\hline Total & 12 & 34.3 & 23 & $\mathbf{6 5 . 7}$ & 35 & 100 \\
\hline
\end{tabular}

Primary data sources 2020

Table 5.Shows that of the 35 respondents studied, the majority of respondents' attitudes were not good as many as 23 people (65.7\%), while 11 people with poor knowledge $(31.4 \%)$ and 24 respondents with good knowledge $(68 \%)$ which is good as many as 12 people $(34 \%)$.

Table 6. Attitudes towards Actions of Managers, Traders and Visitors in Pasar Daya Makassar City

\begin{tabular}{|l|c|c|c|c|c|c|}
\hline \multirow{3}{*}{ Attitude } & \multicolumn{6}{|c|}{ Action } \\
\cline { 2 - 7 } & \multicolumn{2}{|c|}{ Good } & \multicolumn{2}{c|}{ Less } & \multicolumn{2}{c|}{ Total } \\
\cline { 2 - 7 } & $\boldsymbol{n}$ & $\mathbf{\%}$ & $\boldsymbol{n}$ & $\mathbf{\%}$ & $\boldsymbol{n}$ & $\mathbf{\%}$ \\
\hline Good & 6 & 17.1 & 6 & 17.1 & 12 & 34.3 \\
\hline Less & 5 & 14.3 & 18 & 51.4 & 23 & $\mathbf{6 5 . 7}$ \\
\hline Total & 11 & 31.4 & 24 & $\mathbf{6 8 . 6}$ & 35 & 100 \\
\hline
\end{tabular}

Primary data sources 2020

Table 6.Shows that of the 35 respondents studied, the majority of respondents had a bad attitude as many as 23 people $(65.7 \%), 24$ people $(68.6 \%)$ had bad actions and 12 people $(34 \%)$ had a good attitude. good respondents as many as 11 people $(31.4 \%)$ 
Table 7. Attitudes towards Actions of Managers, Traders and Visitors in Pasar Daya Makassar City

\begin{tabular}{|l|c|c|c|c|c|c|}
\hline \multirow{3}{*}{ Knowledge } & \multicolumn{3}{|c|}{ Good } & \multicolumn{2}{c|}{ Action } & \multicolumn{2}{c|}{ Total } \\
\cline { 2 - 7 } & $\boldsymbol{n}$ & $\boldsymbol{\%}$ & $\boldsymbol{n}$ & $\boldsymbol{\%}$ & $\boldsymbol{n}$ & \% \\
\cline { 2 - 7 } & 9 & 25.7 & 15 & 42.9 & 24 & $\mathbf{6 8 . 6}$ \\
\hline Good & 2 & 5.7 & 9 & 25.7 & 11 & 31.4 \\
\hline Total & 11 & 31.4 & 24 & $\mathbf{6 8 . 6}$ & 35 & 100 \\
\hline
\end{tabular}

Primary data sources 2020

Table 7. Shows that of the 35 respondents studied, it was found that the majority of respondents had good knowledge as many as 24 people (68.6\%) with good actions as many as 11 people (31.4\%). Meanwhile, the respondent's actions were not good as many as $24(68.6 \%)$ with poor knowledge as many as 11 people (31.4\%).

Based on the results of larval density observations conducted at Pasar Daya, Makassar City, the Density Figure (DF) results were classified as high. This is because there are still many water reservoirs (TPA) such as water tanks, buckets and drums in Pasar Daya which are not properly cleaned, water is allowed to flow and is not drained properly and routinely. This is supported by Gifari's research (2017), that there is a relationship between the behavior of the $3 \mathrm{M}$ Plus Movement and the presence of Ae.aegypti larvae.

Non-TPA containers such as used tires, used cans and other used goods are still quite abundant with larvae. This is because most market cleaners pay less attention to the cleanliness of the environment around the market. There is a significant relationship between the behavior of cleaners and the presence of Ae.aegypti larvae (Caillouët et al., 2008; Yudhastuti et al., 2016; Walker et al., 2018).

The implementation of PSN by draining the proper landfill is very effective in reducing the presence of mosquito larvae. The implementation of PSN in the form of landfill drainage has a significant effect in reducing the presence of larvae.Based on this, it is hoped that in each region it can increase the larva free rate, so that by increasing the larva free rate it can break the life cycle of mosquitoes so that population density and mosquito regeneration will decrease (Ishak et al., 2019).

Based on the observation results of Ae.aegypti larvae in containers, from 35 houses examined, 18 houses were positive for Ae.aegypti larvae and 17 houses that were not found Larvae with high Density Figure (DF) values. According to researchers this is because the behavior of respondents in the habit of closing the TPA and cleaning containers / containers has not become a routine habit, and the technique, as well as the time for draining is not quite right. In line with the research of Dalila et al (2019), it shows that there is a significant relationship between 3M plus behavior and the presence of Ae.aegypti mosquito larvae.

The high density of Ae.aegypti larvae is a risk for dengue transmission. According to Khayati \& Suhartono (2019) people who live in homes with high CI have a 4 times risk of developing dengue hemorrhagic fever than people who live in homes with low CIs. This is in line with the research of Sari et al. (2017) showing that there is a significant relationship between the presence of Aedes spp larvae and the incidence of dengue fever. 
Collecting conditions and standing water in a humid place that is not exposed to sunlight are the factors in the presence of Ae.aegypti larvae. Air humidity is an important factor in the growth of mosquitoes in their lives, and humidity affects the habits of mosquitoes to lay their eggs (Yahya et al., 2019).

High humidity affects mosquitoes to seek damp and wet places as breeding or resting areas. In line with the research of Ibrahim et al (2018), there is a relationship between water temperature, house humidity, and container conditions and the presence of larvae in endemic areas.

The condition of the containers around the dwellings and the community's efforts to control the Ae.aegypti population determine the presence of larvae around human dwellings (Wang et al., 2020). The eradication of mosquito nests (PSN) through vector control is quite effective in breaking the chain of DHF transmission. In line with the research of Ishak et al (2019), it shows that PSN actions carried out in most endemic areas are categorized as good, with a low density of ae.aegypti larvae, and supported by research by Azlina et al (2017), that there is a relationship between mosquito nest eradication measures and presence of larvae.

Based on the research results, it shows that the majority of respondents' knowledge, attitudes and actions are in the unfavorable category. Based on this, the majority of respondents do not know about the importance of controlling dengue and do not know about the risks caused by dengue disease.

This can be caused by a lack of information such as previous outreach / counseling on how to deal with dengue fever by implementing the 3M Plus PSN and periodic larva monitoring obtained from local health workers, the neighborhood, or electronic media. According to Listyorini (2016), it is stated that knowledge, attitudes, availability of information, and the role of health workers influence the behavior of eradicating dengue mosquito nests in the community.

The implementation of PSN is an important factor in preventing DHF. according to Notoatmodjo (2010) action is an activity or activity of a person focused on something, or action is a real behavior shown to a known object.

Based on the results of the level of knowledge of the respondent's attitude, it shows that the knowledge of the majority of respondents is in the good category of $68.6 \%$, while the attitude of the majority of the respondents is not good at $65.7 \%$, which means that the majority of respondents' knowledge level is good, has a bad attitude.

This is not in line with Ifkar's research (2018) which shows that there is a relationship between knowledge and attitudes in preventing dengue, and research by Ensia et al (2016) that there is a relationship between knowledge and people's attitudes about the implementation of $3 \mathrm{M}$, this shows that with knowledge that is both tend to have a good attitude towards the implementation of $3 \mathrm{M}$ in overcoming DHF. This proves the theory which states that good knowledge does not yet have an important role in getting a good attitude, because it is very difficult to change one's behavior. The opposite can also happen, that a person can act first without knowing the meaning of the stimulus it receives. This means that a person's attitude does not have to be based on good knowledge.

The unfavorable attitude towards the prevention of DHF indicates that respondents do not take seriously the dangers of dengue disease which can be fatal. Respondents will not feel the need to seek immediate treatment if they are infected with dengue. 
Based on the results of the respondent's level of knowledge of the PSN action, it was found that the majority of respondents 'knowledge level was good at $68.6 \%$ while the majority of respondents' actions were in the unfavorable category of $65.7 \%$. This is supported by research by Azfar et al (2017) which found no significant relationship between the level of knowledge and practices of dengue fever prevention. As well as research by Kurniawan et al (2017) shows that there is no relationship between knowledge of DHF and PSN behavior.

Based on this, some respondents have knowledge about dengue fever caused by the Ae.aegypti mosquito, but do not yet know how much risk it causes. So that public awareness in preventing DHF is still not good.

Public awareness is an important factor in the implementation of the 3M Plus Mosquito Nest Eradication, with awareness enabling individuals to be able to take action in taking action. In line with Ramadhani et al (2017), it is shown that the implementation of 3M Plus Mosquito Nest Eradication is not optimal because someone is at the Naival Consciousness stage. When someone is at the Naival Consciousness stage, they are not able to connect between maintaining environmental cleanliness and the Eradication of $3 \mathrm{M}$ Plus Mosquito Nests and the incidence of DHF. based on this awareness, the public will be moved to participate in the implementation of the 3M Plus Mosquito Nest Eradication.

Based on this, it is necessary to provide information such as counseling or training in the form of 3M Plus Mosquito Nest Eradication which can be a stimulus, so that the public can accept and respond to the stimulus. It is hoped that this can change people's behavior in the effort to tackle dengue by eradicating the $3 \mathrm{M}$ Plus Mosquito Nests.

Based on the results of the respondent's attitude towards the Mosquito Nest Eradication action, it shows that the attitudes and actions of the majority of respondents are in the unfavorable category of $68.6 \%$. This can be interpreted that someone who has a bad attitude towards something will take bad actions and vice versa if someone has a good attitude towards something, he will take good action against that something. In line with the research of Hasyim et al (2016) conducted in Masuji Regency, that there is a relationship between the respondent's attitude and the act of eradicating dengue mosquito nests.

Attitude is one of the most important factors for an individual to react or respond to a situation. According to Adri (2016), the better a person's attitude in preventing dengue fever, the better the prevention of dengue fever.

based on this to improve attitudes and actions of a person in dealing with DHF. Community empowerment to carry out the Mosquito Nest Eradication movement is a strategy that can be implemented by the local government. Strengthening the work program of the Community Health Center (Puskesmas) by activating cross-related sectors, especially in sub-districts with a focus on community empowerment in activating the implementation of the DHF working group (pokja) function at the village and sub-district levels in the form of jumantik cadre activities is an important step.

Cross-sectoral involvement is important in the prevention of DHF, because activities will be more focused and more effective, especially in efforts to increase community participation. According to Sukowati, (2010) states that community empowerment in the form of involvement of all elements of society in the DHF eradication movement is a key step to the success of the 
DHF program and it is impossible to succeed without the role of the local government, and crossrelated sectors such as education, religion, non-governmental organizations (NGOs) and others.

\section{Conclusion}

The density of Ae.aegypti larvae in containers at Pasar Daya, Makassar City is in the high density category, and there are still quite a lot of Ae.aegypti larvae found in the respondent's house. Knowledge, attitudes and actions of cleaning managers, merchants and market visitors are still not good. and in this study shows that a good level of knowledge is not in line with the attitude of the respondent, as well as knowledge and action. Different things are shown in the attitudes and actions of the respondents that the unfavorable attitude is in line with the actions obtained.

\section{References}

Adri, A. M. (2016). Hubungan Pengetahuan dan Sikap terhadap Tindakan Pencegahan Demam Berdarah Dengue pada Masyarakat di Kecamatan Baiturrahman. ETD Unsyiah.s

Azfar, M., Omarulharis, S., Azfar, H., Maryam, A., Hafizah, S., Adibah, B. A. H., \& Akmal, N. (2017). Knowledge, attitude and practice of dengue prevention among sub urban community in Sepang, Selangor. International Journal of Public Health and Clinical Sciences, 4(2), 73-83.

Azlina, A., Adrial, A., \& Anas, E. (2016). Hubungan tindakan pemberantasan sarang nyamuk dengan keberadaan larva vektor DBD di Kelurahan Lubuk Buaya. Jurnal Kesehatan Andalas, 5(1).

Boekoesoe, L. (2015). Ancaman Demam Berdarah Dengue Analisa Temuan Kasus Di Kota Gorontalo. Makassar: Samudera Himalaya.

Caillouët, K. A., Keating, J., \& Eisele, T. P. (2008). Characterization of aquatic mosquito habitat, natural enemies, and immature mosquitoes in the Artibonite Valley, Haiti. Journal of Vector Ecology, 33(1), 191-197.

Dalilah, D., Kinanti, A., Aulia, H., \& Ghiffari, A. (2019). Hubungan pengetahuan, sikap dan perilaku masyarakat terhadap Demam Berdarah Dengue (DBD) dengan keberadaan larva nyamuk di Rt. 03 Sako Baru kota Palembang. In Prosiding Seminar Nasional Perhimpunan Entomologi Indonesia (PEI) Cabang Palembang (Vol. 1, No. 1, pp. 195202).

Ensia, M. A., Wiyono, H., \& Araini, M. S. (2016). Hubungan Pengetahuan Dengan Sikap Masyarakat Tentang Pelaksanaan 3M (Menguras, Mengubur Dan Menutup) Dalam Mengatasi Kejadian Dbd Dan Zika Di Wilayah Kerja Puskesmas Jekan Raya Tahun 2016. Dinamika Kesehatan: Jurnal Kebidanan Dan Keperawatan, 7(1), 243-248.

Gifari, M. A., Rusmartini, T., \& Astuti, R. D. I. (2017, September). Hubungan tingkat pengetahuan dan perilaku gerakan 3M Plus dengan keberadaan jentik Aedes aegypti. In Bandung Meeting on Global Medicine \& Health (BaMGMH) (Vol. 1, No. 1, pp. 8490).

Hasyim, D. M. (2016). Faktor-faktor yang Berhubungan dengan Tindakan Pemberantasan Sarang Nyamuk Demam Berdarah Dengue (PSN DBD). Jurnal Kesehatan, 4(2). 
Ibrahim, E., Manyullei, S., \& Sumarni, S. (2019). Studi Keberadaan Larva Aedes Aegypti Sebelum Dan Sesudah Intervensi Psn Dbd Di Kelurahan Pandang Kecamatan Panakukang Kota Makassar. Jurnal Nasional Ilmu Kesehatan, 2(2), 109-120.

Ifkar, M. J. L. (2019). Hubungan pengetahuan dengan sikap dan perilaku pencegahan demam berdarah dengue pada masyarakat. Thesis, Universitas Trisakti.

Ishak, H., Toding, N., Natsir, M. F., \& Amqam, H. (2019). Description of Aedes aegypti Larva Density Based on Mosquito Breeding Eradication Action in the Dengue Endemic Rappocini Sub-District Makassar. Proceedings of the 3rd International Conference on Environmental Risks and Public Health, ICER-PH 2018, 26-27, October 2018.

Kementrian Kesehatan RI, (2019a). Profil Kesehatan Indonesia. Jakarta. Indonesia. Available From: https://www.kemkes.go.id/folder/view/01/structure-publikasi-pusdatin-profilkesehatan.html

Kementrian Kesehatan RI (2019b). Satu Rumah Satu Jumantik Efektif Cegah DBD. (Online). Jakarta. Indonesia. http://sehatnegeriku.kemkes.go.id/baca/rilismedia/20190129/3629259/satu-rumah-satu-jumantik-efektif-cegah-dbd/

Khayati, D. N., Adi, M. S., \& Suhartono, S. (2019). Analisis Faktor Yang Berhubungan Dengan Kejadian Demam Berdarah Dengue Di Daerah Endemis Di Kabupaten Temanggung. Thesis, School of Postgraduate, Universitas Diponegoro.

Kurniawan, M. E., Mohamed, A. M. D., Siyam, N., Fatikha, N., \& Fitriani, N. A. (2017). Relation Between Knowledge and Attitude Regarding DHF with PSN Behavior Among the Community Around the Campus. KEMAS: Jurnal Kesehatan Masyarakat, 13(2), 145-151.

Listyorini, P. I. (2016). Faktor-Faktor Yang Mempengaruhi Perilaku Pemberantasan Sarang Nyamuk (PSN) Pada Masyarakat Karangjati Kabupaten Blora. Infokes: Jurnal Ilmiah Rekam Medis dan Informatika Kesehatan, 6(1).

Maharani, D. Y. (2019). Hubungan Hasil Pemeriksaan Penunjang Terhadap Manifestasi Perdarahan Pasien Demam Berdarah Dengue Di SMF Anak RSUD Dr. A. Dadi Tjokrodipo Bandar Lampung. Thesis, Universitas Lampung.

Notoatmodjo, S. (2010). Ilmu perilaku kesehatan. Jakarta: rineka cipta, 200, 26-35.

Prasetyowati, H., Marina, R., Widawati, M., \& Wahono, T. (2014). Survey jentik dan aktifitas nokturnal Aedes spp. di Pasar Wisata Pangandaran. Indonesian Journal of Health Ecology, 13(1), 33-42.

Ramadhani, F., Yudhastuti, R., \& Widati, Sri. (2019). Pelaksanaan PSN 3M Plus untuk pencegahan demam berdarah dengue (studi kasus Masyarakat desa kamal). Unigo, 2(2).

Sari, I. P., Adrial, A., \& Nofita, E. (2017). Hubungan Kepadatan Larva Aedes spp. dengan Kejadian Demam Berdarah Dengue di Kelurahan Lubuk Buaya Kecamatan Koto Tangah Kota Padang. Jurnal Kesehatan Andalas, 6(1), 41-48.

Sukowati, S. (2010). Masalah vektor demam berdarah dengue (DBD) dan pengendaliannya di Indonesia. Buletin Jendela Epidemiologi, 2(1), 26-30. 
Walker, K. R., Williamson, D., Carrière, Y., Reyes-Castro, P. A., Haenchen, S., Hayden, M. H., ... \& Ernst, K. C. (2018). Socioeconomic and human behavioral factors associated with Aedes aegypti (Diptera: Culicidae) immature habitat in Tucson, AZ. Journal of medical entomology, 55(4), 955-963.

Wang, Y., Marin-Lopez, A., Jiang, J., Ledizet, M., \& Fikrig, E. (2020). Vaccination with Aedes aegypti agbr1 delays lethal mosquito-borne Zika virus infection in mice. Vaccines, 8(2), 145.

Yahya, Y., Ritawati, R., \& Rahmiati, D. P. (2019). PENGARUH SUHU RUANGAN, KELEMBAPAN UDARA, pH DAN SUHU AIR TERHADAP JUMLAH PUPA Aedes aegypti STRAIN LIVERPOOL (LVP). SPIRAKEL, 11(1), 16-28.

Yudhastuti, R., Rasjid, A., \& Notobroto, H. B. (2016). Relationship of environmental condition, container and behavior with the existence of Aedes aegypti mosquito larvae in an endemic area of dengue hemorrhagic fever, Makassar. Pakistan Journal of Nutrition, 15(3), 295-298. 